\title{
The Downhill Braked Railway Wheel Structural Analysis by Means of the ANSYS Multiphys- ics Program System Package
}

Andrej Suchánek, Jozef Harušinec

University of Žilina, Faculty of Mechanical Engineering, Department of Transport and Handling Machines, Univerzitná 1, 01026 Žilina, tel.: +421 (41) 513 2554, e-mail: andrej.suchanek@fstroj.uniza.sk, jozef.harusinec@ fstroj.uniza.sk

\begin{abstract}
Article deals with the detection of reduced stress in a braked railway wheel based on thermal transient analysis on virtual models, because they influence the characteristics of the railway wheels. Structural analysis was performed by means of the ANSYS Multiphysics program system package. Thermal transient analysis deals with the detection of temperature fields which are result of braking by brake block. The applied heat flux represents the heat generated by friction of brake block. It is applied to the quarter model because of the acceleration calculation. This analysis simulates two braking with subsequent by cooling. Distribution of the equivalent stress was detected in the cross section railway wheel, at selected points. The input parameters were used from the thermal transient analysis. These equivalent stresses result due to thermal load.
\end{abstract}

Keywords: railway wheel, brake block, residual stress, transient thermal analysis

\section{Acknowledgement}

The work was supported by the Scientific Grant Agency of the Ministry of Education of the Slovak Republic and the Slovak Academy of Sciences in project No. 1/0347/12: "Railway wheel tread profile wear research under the rail vehicle in operation conditions simulation on the test bench", project No. 1/0383/12: "The rail vehicle running properties research with the help of a computer simulation." and the project No. APVV-0842-11: "Equivalent railway operation load simulator on the roller rig".

\section{References}

[1] GERLICI, J., ŘEZNÍ́ČEK, R. (1994). Temperature fields in the brake blocks when braking on an incline; XI. International conference "Current problems in rail vehicles". (In Slovak), pp. 233-244, Česká Třebová, 13.- 14. 9. 1994.

[2] GERLICI, J., LACK, T. et al. (2005). Transport Means Properties Analysis. Vol. I. (2005), str. 214, ISBN 808070-408-2, EDIS - Publishing Institution of the University of Zilina, Zilina 2005.

[3] SUCHÁNEK, A., GERLICI, J., HARUŠINEC, J., LACK, T. (2013): Analysis of temperature distribution in a braked railway wheel during braking by the brake block. In: TRANSCOM 2013, section 6, pp. 289-292. EDIS - Publishing Institution of the University of Zilina, 2013. ISBN 978-80-554-0695-4.

[4] ̌EZNÍČEK R., GERLICI J., LACK T. (1993). Stress analysis monoblock wheels braked by FEM (In Slovak). In: proceedings: ŽELSEM '93, Savings in railway", University of Zilina 1993, pp. 155-161, Loučeň, 1993.

[5] GERLICI, J., HLAVŇA, V., ŘEZNÍČEK R. (1994). Simulation of down-hill braking with a shoe brake, 4.th mini conference on vehicle system dynamic, identification and anomalies. Technical university of Budapest, 1994.

[6] GERLICI, J., LACK, T., KALINČÁK, D. (2003). Laboratory simulation of braking with a shoe brake. Pp. 8392. In: SITARZ, M.: Railway wheelsets. Monograph. ISBN 83-7335-151-5. Chapter 5. Pp. 83-92. Silesian university of technology, Gliwice Poland, 2003.

[7] LACK, T., GERLICI J. (2005). Contact area and normal stress determination on railway wheel / rail contact. Communications, the scientific letters of the University of Zilina, 1/2005, pp. 38-45, ISSN 1335-4205, EDIS Publishing Institution of the University of Zilina 2005.

[8] MAN, K. W. (1994). Contact mechanics using boundary elements. Topics in engineering. Volume 22. Computational mechanics publication. ISBN: 185312334 X. p. 185. Southampton 1994.

[9] LACK, T., GERLICI J. (2005). Modified Strip Method utilisation for wheel /rail contact stress evaluation In: 9th international conference on contact mechanics and wear of rail/ wheel systems (CM2012): 27-30 August 2012, Chengdu, China: proceedings. - Chengdu: Southwest Jiaotong University, 2012, pp. 87-89.

[10]LACK, T., GERLICI J. (2013). Wheel/rail contact stress evaluation by means of the modified Strip method. In: Communications: scientific letters of the University of Žilina. - ISSN 1335-4205. - Vol. 15, no. 3 (2013), pp. 126-132. 
[11]LACK, T., GERLICI J. (2014). Wheel/rail tangential contact stress evaluation by means of the modified strip method. In: Communications: scientific letters of the University of Žilina. - ISSN 1335-4205. - Vol. 16, no. 3A (2014), s. 33-39.

[12]LACK, T., GERLICI J. (2014). A modified strip method to speed up the calculation of normal stress between wheel and rail. In: Applied mechanics and materials. - ISSN 1660-9336. - Vol. 486 (2014), pp. 359-370.

[13]LACK, T., GERLICI J. (2013). The FASTSIM method modification in speed up the calculation of tangential contact stresses between wheel and rail. In: Manufacturing technology: journal for science, research and production. - ISSN 1213-2489. - Vol. 13, no. 4, pp. 486-492.

[14]LACK, T., GERLICI J. (2014). A modified strip method to speed up the tangential stress between wheel and rail calculation. In: Applied mechanics and materials. - ISSN 1660-9336. - Vol. 486 (2014), pp. 371-378.

[15]GERLICI, J., LACK, T. (2010). Contact geometry influence on the rail /wheel surface stress distribution. Science direct. Procedia Engineering. ISSN 1877-7058, pp. 2249-2257. Elsevier Ltd. 2010.

[16]LACK, T., GERLICI J. (2006). The usage of arcs radii profile variation for the synthesis of railway wheel and rail head profiles. In: Komunikácie - vedecké listy Žilinskej univerzity = Communications - scientific letters of the University of Žilina. ISSN 1335-4205. Vol. 8, No. 2 (2006), pp. 57-69.

[17] GERLICI, J., LACK, T. (2009). Iterative method for railway wheel profile design. In: Communications: Scientific Letters of the University of Žilina. ISSN 1335-4205. - Vol. 11, No. 2 (2009), pp. 49-56.

[18] GERLICI, J., LACK, T. (2011). Railway wheel and rail head profiles development based on the geometric characteristics shapes. In: Wear: an international journal on the science and technology of friction, lubrication and wear. - ISSN 0043-1648. - Vol. 271, No. 1-2 Sp. iss. (2011), pp. 246-258, 2011.

[19]GERLICI, J., LACK, T., HARUŠINEC, J. (2013). The test stand load modulus implementation for the realistic railway operation in the laboratory conditions. In: Manufacturing technology: journal for science, research and production. - ISSN 1213-2489. - Vol. 13, no. 4 (2013), pp. 444-449.

[20]HARUŠINEC, J., SUCHÁNEK, A., GERLICI, J., LACK, T. (2012). Locomotive brake unit modification for laboratory experimental tests. (In Slovak). In: DTDT 2012. J. E. Purkyně University, 2012 - ISBN 978-80-7414510-0.

[21]GERLICI, J., LACK, T. (2003). Test benches computer control software tools development. In: Scientific bulletin of North University of Baia Mare: Fascicle: Mechanics, Tribology. Technology of Machine Manufacturing. - ISSN 1224-3264. - Series C, Vol. XVII (2003), pp. 181-186, Baia Mare 2003.

[22] VLK et al. (2003): Experimental mechanics. (In Czech), Chapter 6.1 Introduction into experimental determination of residual stresses. Brno university of technology, pp.119-123.

[23]SUCHÁNEK, A., HARUŠINEC, J., GERLICI, J., LACK, T. (2013): Analysis of models for simulation computations and experimental detection of stress in braked railway wheel. In: TRANSCOM 2013, section 6, pp. 283 287. EDIS - Publishing Institution of the University of Zilina, 2013. ISBN 978-80-554-0695-4.

[24]SUCHÁNEK, A. (2014): Analysis of stress distribution in a braked railway wheel (In Slovak), PhD. thesis, University of Zilina, Faculty of Mechanical Engineering, p.153. 